\title{
Characterization of Determinate Tomato Hybrids: Search for Better Processing Qualities
}

\section{Arup Chattopadhyay ${ }^{1 *}$, IVI Chakraborty ${ }^{2}$ and Wasim Siddique ${ }^{2}$}

${ }^{1}$ All India Coordinated Research Project on Vegetable Crops, Directorate of Research, Bidhan Chandra Krishi Viswavidyalaya, Kalyani-741235, Nadia, West Bengal, India ${ }^{2}$ Department of Post Harvest Technology of Horticultural Crops, Faculty of Horticulture, Bidhan Chandra Krishi Viswavidyalaya, Mohanpur-741252, Nadia, West Bengal, India

\begin{abstract}
Thirty-one determinate tomato hybrids developed by both public and private sectors in India over the years were characterized in order to select the most appropriate hybrids for processing purpose. The performance of each hybrid was evaluated using certain physical and chemical indices. Most quality indices showed significant differences between hybrids, although their values remained in the typical ranges for processing tomatoes. In our study, two pear shaped private bred hybrids (BSS-423; $\mathrm{TH}-1359$ ) qualified all the physico-chemical characteristics required for processing. However, three round shaped public (BCTH-62 and BCTH-4) and private (Vijay Lakshmi) bred hybrids also showed great promise for requisite qualification. The promising hybrids also showed high yield potential (> $60.0 \mathrm{t} / \mathrm{ha}$ ) which is the general acceptance criteria among the farmers. The correlation study indicates some significant positive relationship between polar diameter and pericarp thickness, equatorial diameter and locule number, titratable acidity and vitamin $\mathrm{C}$ content, and lycopene and total carotenoids content of the fruit. The data generated in this study is of equal significance for the growers as well as for the tomato processors in the long run.
\end{abstract}

Keywords: Tomato; Hybrid; Yield; Processing quality

\section{Introduction}

Tomato (Solanum lycopersicum) is one of the important crops used as fresh vegetable as well as a variety of processed products such as juice, ketchup, sauce, canned fruits, puree, paste, etc. Tomato and tomato products made its attention even in terms of value of micronutrients existing at low concentration. Apart from contributing nutritive elements, colour and flavour to the diet, tomatoes are also a valuable source of antioxidants, or chemo-protective compounds, and may thus be termed a "functional food" [1]. The antioxidant potential of tomato is derived from a mixture of antioxidant biomolecules, including lycopene, ascorbic acid, phenolics, flavonoids and vitamin $\mathrm{E}$, and is especially high in cherry tomatoes [2]. Because of their importance to human health [3], antioxidants may be considered a valuable quality attribute of tomatoes and it is important to minimize losses of these compounds during the post-harvest period. Tomato ranks $11^{\text {th }}$ as the possible sources of Vitamin A and $25^{\text {th }}$ for Vitamin C among the vegetables grown in India [4]. A beneficial effect of tomato consumption in the prevention of some chronic diseases such as some type of cancer and cardiovascular diseases has been reported [5]. Apart from the nutritional and antioxidant vitamin contents, sugars and organic acids, which form a substantial fraction of tomato dry matter, are relevant more to taste attributes than to the nutritional value of tomato, with tomato antioxidants playing a major role in the latter aspect [6]. Quality and flavour of the processed products depend on chemical components like reducing sugar, acidity, ascorbic acid, lycopene, $B$-carotene, T.S.S. and total sugar which has been reported to vary greatly with variety [7]. The desirable qualities for a tomato cultivar to be used for processing includes high total soluble solids (4- $8^{\circ}$ Brix), acidity not less than $0.4 \%, \mathrm{pH}$ less than 4.5 , uniform red colour, smooth surface, free from wrinkles, small core, firm flesh and uniform ripening [8].

There is an extensive 60-year literature on the quality of processed tomato products and on breeding cultivars to suit processing needs. There has also been considerable research on tomato agronomy, yet there are clearly large gaps in the understanding of how the field environment and crop management influence each of the fruit properties measured at harvest to estimate the quality of processed products. Tomato paste is the product of most interest since it is reformulated into many other products. The market of tomato processing products around the world are expanding whereas, in the tropics, the tomato processing industry often confronted with the problem of limited supply of processing tomatoes. Low yield increases the cost and the risk of growing tomatoes. Therefore, farmer's income is decreased. Scientists from the tropical regions have identified the reasons why tomato varieties grow in these areas are unadapted. The reasons fall into three main categories, i.e., susceptibility to diseases, low fruit setting ability and poor quality fruits. However, in the developing countries of wet and humid tropics, there are far more important steps that need to be taken. First is to improve the processing tomato varieties to adaptable varieties of the tropics, since the potential for tomatoes in tropics is great.

In most of the advanced countries, nearly $80 \%$ of the fresh tomatoes are processed into various products. Currently, only $2.2 \%$ of the total produce in India is processed and the rest marketed as fresh vegetables [9]. Tomato quality depends on many factors such as cultivar, growing condition and ripening on and off the vine. The physical and chemical characteristics of tomato also affect the quality of processed product. Therefore, good quality tomatoes should be processed for the best products. High yield coupled with good processing qualities are the pre-requisites for the general acceptance of the hybrid by the farmers. However, very little attempt has been made so far to assess the physical

${ }^{*}$ Corresponding author: Arup Chattopadhyay, All India Coordinated Research Project on Vegetable Crops, Directorate of Research, Bidhan Chandra Krishi Viswavidyalaya, Kalyani-741235, Nadia, West Bengal, India, E-mail chattopadhyay.arup@gmail.com

Received January 23, 2013; Accepted February 22, 2013; Published February 28, 2013

Citation: Chattopadhyay A, Chakraborty IVI, Siddique W (2013) Characterization of Determinate Tomato Hybrids: Search for Better Processing Qualities. J Food Process Technol 4: 222. doi:10.4172/2157-7110.1000222

Copyright: (C) 2013 Chattopadhyay A, et al. This is an open-access article distributed under the terms of the Creative Commons Attribution License, which permits unrestricted use, distribution, and reproduction in any medium, provided the original author and source are credited. 
and chemical properties of tomato hybrids developed by both public and private sectors in recent times from the point of view of processing. The present study was, therefore, conducted to assess the processing qualities of determinate tomato hybrids which would be acceptable by the processing industries.

\section{Materials and Methods}

Thirty one determinate tomato hybrids developed by both public and private sectors were evaluated during autumn-winter season in the Research Farm of Bidhan Chandra Krishi Viswavidyalaya, West Bengal, India, situated at $23.5^{\circ} \mathrm{N}$ latitude and $89^{\circ} \mathrm{E}$ longitude with a mean sea level of $9.75 \mathrm{~m}$.

Seed beds were prepared in a sandy loam soil and were $20 \mathrm{~cm}$ tall and $1.0 \mathrm{~m}$ wide. Weathered cowdung manure @ $4 \mathrm{~kg} / \mathrm{m}^{2}$ was mixed into the beds. Beds were drenched with formaldehyde $(4.0 \%)$ and covered with polythene sheet for 10 days to avoid damping off disease. Seeds, after treatment with Thiram ( $3 \mathrm{~g} / \mathrm{kg}$ of seed), were sown during the 1st week of August, 2010 at shallow depth $5 \mathrm{~cm}$ apart and covered with finely sieved leaf mold. After sowing, beds were covered with straw until germination and hand watered regularly. Nursery beds were covered with $200 \mu \mathrm{m}$ ultraviolet (UV)-stabilized polyethylene film supported by bamboo poles with open sides to protect seedlings from rain and direct sunlight. Seedlings were hardened by withholding water 4 days before transplanting. One-month seedlings, at least 15 $\mathrm{cm}$ in height with 3-4 leaves, were transplanted to the main field at a spacing of $60 \times 45 \mathrm{~cm}$ apart in the plot size of $3.6 \mathrm{~m} \times 4.5 \mathrm{~m}$ during the $1 \mathrm{st}$ week of September, 2010. Management practices for cultivation were followed as per Chattopadhyay et al. [10]. The data on fruit yield (t/ha) of hybrids were calculated on plot yield basis.

Fresh red ripe fruits at an earlier stage of maturity of thirty one hybrids were collected from the field during December-January and brought to the laboratory of Post Harvest Technology of Horticultural Crops, Directorate of Research, Kalyani, West Bengal for determination of different physico-chemical parameters. There was a distinct pattern of higher quality in the latest-set (youngest) fruit in terms of total solids, ${ }^{\circ}$ Brix (soluble solids), and titratable acidity as observed by Renquist and Reid [11]. After taking different morphological characters of fruits like fruit shape, colour (as per documented descriptors), weight, polar and equatorial diameter (by Digital slide calipers), pericarp thickness (Digital slide calipers), number of locules/fruit, ten random sampled fruits from each replication were used to estimate different biochemical constituents like total soluble solids (by digital hand refractometer), titratable acidity (in terms of citric acid) [12], $\mathrm{pH}$ (by digital $\mathrm{pH}$ meter), ascorbic acid (Indophenol method) as suggested by Ranganna [13], lycopene and total carotenoid contents [13] following standard methods.

The experiment was conducted by following Randomized Block Design with three replications. Data were subjected to ANOVA for a Randomized Block Design with three replications according to Gomez and Gomez [14] and simple correlations were worked out and tested for significance.

\section{Results and Discussion}

Nine out of thirty one tomato hybrids were pear shaped and rest of the hybrids were either round or flattish round in shape. Fruit weight of tomato plays an important role in consumer preference as well as in processing industry. The present study revealed that tomato had a wide and significant variation in fruit weight among the different hybrids. The mean weight of the fruit ranged from $42.00 \mathrm{~g}$ to $134.40 \mathrm{~g}$ and the maximum being in Aruna, whereas the minimum was found in $\mathrm{HTH}$ 2-2 (Table 1). Six pear shaped and twelve round shaped red coloured hybrids were having fruit weight of more than $80 \mathrm{~g}$ (Table 2).

A wide range $(3.18 \mathrm{~cm}$ to $6.48 \mathrm{~cm}$ ) of variation was recorded among the different hybrids in respect of their mean polar diameter with the maximum in Crystal-448 $(6.48 \mathrm{~cm})$ followed by TH-1359 $(5.96 \mathrm{~cm})$ and BSS-423 $(5.46 \mathrm{~cm})$ and the minimum in HTH-2-2 (Table 1). Hybrids with high polar diameter and having pear shape are desired for processing purpose as the fruit contains more pulp as reported by Tiwari [15]. Like polar diameter, the maximum equatorial diameter was observed in HTH-2-2 $(6.36 \mathrm{~cm})$, whereas minimum in SHTH-1 $(3.94 \mathrm{~cm})$

Number of locules in the fruit is an important trait for selection of hybrids for processing. There should be minimum number of locules (2-3) for proper shape of the fruit and at the same time favours high concentration of solids and ascorbic acid content [16]. Ascorbic acid is present in higher concentration in the locules than in the pericarp tissue. In the present study, a slight variation in locule number of different hybrids was observed with the minimum 2.0 in TH-1359 followed by Roopsi (2.2), BSS-423 (2.3), ARTH-1001 (2-4) and the maximum 4.40 in HTH-2-2 (Table 1). Usually pear/oblong shaped varieties (higher polar diameter) have lower number of locules $[17,18]$. This observation corroborates the present finding, where genotype (TH-1359, Roopsi, BSS-423, ARTH-1001) with minimum (2.0-2.4) number of locules registered higher polar diameter. On the other hand, round-fruited hybrids with higher equatorial diameter (HTH-2-2, VLTH-1, ARTH3 ) had more number of locules (more than 4.0 ) which corroborated the findings earlier worker [19].

Thickness of the pericarp also bears an important quality attributes for processing purpose [20]. Tomatoes with thicker pericarp would stand long distance transport and keep well [21]. Thus, tomatoes for processing should have more than $0.50 \mathrm{~cm}$ of pericarp thickness which would keep the fruit firm and evaporation of water through surface would be less [15]. A significant variation was observed on pericarp thickness of the fruit (Table 1). Among the hybrids, JKTH-2040 had the maximum $(1.02 \mathrm{~cm})$ pericarp thickness while $\mathrm{HTH}-2-2$ had the minimum $(0.36 \mathrm{~cm})$ pericarp thickness. Shape and size also bears a strong relationship with pericarp thickness. It was observed in general that pear shaped hybrids (JKTH-2040, ARTH-1023, BSS-437, ARTH1001) had higher pericarp thickness than the round shaped fruits. This result is in accordance with the findings of Thakur and Kaushal [17].

High total soluble solids (TSS) are the main quality component for nutritional and processing purposes [20]. Among the 31 hybrids, the maximum total soluble solids content $\left(5.10^{\circ}\right.$ Brix) was found in Vijay Lakshmi followed by Kundal- 90 (5.00 ${ }^{\circ}$ Brix) and BSS-423 (4.96 ${ }^{\circ}$ Brix). Only two pear shaped and eight round shaped red coloured hybrids were having TSS of more than $4.5^{\circ}$ Brix (Table 2).

Two important quality attributes of processing tomatoes are $\mathrm{pH}$ and titratable acidity [22]. Citric acid is the most abundant acid in tomatoes and the largest contributor to the total titratable acidity [23]. The acidity of the fruit is also important as a contributor to the flavour of the tomato products. Minimum acidity requirement for processing tomato should be $0.40 \%$ as the processed product from low acid tomato may be affected by Bacillus coagulans [16]. The mean acid content of hybrids ranged from 0.27 to 0.52 per cent (Table 3 ). The maximum fruit acidity was recorded in Vijay Lakshmi (0.52 \%) followed by BCTH-4 (0.51\%) and ARTH-1001 (0.50\%). Genotypic variation on the acid content of tomato fruits was highlighted by previous workers [24,25].Three pear 
Citation: Chattopadhyay A, Chakraborty IVI, Siddique W (2013) Characterization of Determinate Tomato Hybrids: Search for Better Processing Qualities. J Food Process Technol 4: 222. doi:10.4172/2157-7110.1000222

Page 3 of 6

\begin{tabular}{|c|c|c|c|c|c|c|c|c|c|}
\hline Entries & Source & Fruit shape & Fruit colour & Fruit Weight (g) & Polar diameter $(\mathrm{cm})$ & $\begin{array}{c}\text { Equatorial } \\
\text { diameter }(\mathbf{c m})\end{array}$ & $\begin{array}{l}\text { Locule } \\
\text { No. }\end{array}$ & $\begin{array}{c}\text { Pericarp } \\
\text { thickness }(\mathrm{cm})\end{array}$ & $\begin{array}{l}\text { Fruit yield } \\
\text { (t/ha) }\end{array}$ \\
\hline ВСТH-62 & Public & Round & Red & 106.0 & 5.16 & 5.00 & 3.8 & 0.51 & 63.7 \\
\hline Ajeet-11 & Private & Pear Shaped & Red & 80.1 & 5.12 & 4.70 & 3.0 & 0.60 & 79.0 \\
\hline ARTH-1023 & Private & Pear Shaped & Red & 126.0 & 5.94 & 4.94 & 3.0 & 0.74 & 69.8 \\
\hline SHTH-3 & Public & Flattish Round & Red & 45.2 & 3.44 & 4.26 & 3.6 & 0.42 & 45.0 \\
\hline SHTH-1 & Public & Round & Red & 42.8 & 3.86 & 3.94 & 3.1 & 0.38 & 54.1 \\
\hline BSS-571 & Private & Round & Red & 95.6 & 4.86 & 5.46 & 3.2 & 0.56 & 72.5 \\
\hline BSS-575 & Private & Round & Red & 69.6 & 4.86 & 4.84 & 3.2 & 0.56 & 68.6 \\
\hline HTH-2-1 & Public & Round & Red & 54.4 & 3.64 & 4.48 & 3.4 & 0.48 & 62.0 \\
\hline UKC-10 & Private & Flattish Round & Red & 62.8 & 3.44 & 4.54 & 3.2 & 0.44 & 67.0 \\
\hline VNR-6A & Private & Round & Red & 82.0 & 4.46 & 4.78 & 3.8 & 0.46 & 57.4 \\
\hline HTH-2-2 & Public & Flattish Round & Red & 42.0 & 3.18 & 6.36 & 4.4 & 0.36 & 48.6 \\
\hline ARTH-3 & Private & Round & Orange Red & 76.0 & 4.46 & 4.98 & 4.2 & 0.44 & 45.7 \\
\hline ARTH-1001 & Private & Pear Shaped & Red & 59.2 & 4.62 & 4.20 & 2.4 & 0.70 & 41.6 \\
\hline HATH-5 & Public & Round & Red & 58.4 & 3.72 & 4.50 & 3.4 & 0.58 & 32.3 \\
\hline HATH-9 & Public & Round & Red & 64.0 & 4.46 & 4.50 & 3.8 & 0.42 & 43.9 \\
\hline NTH-449 & Private & Round & Red & 90.0 & 4.98 & 5.72 & 3.2 & 0.64 & 34.1 \\
\hline JKTH-2040 & Private & Pear Shaped & Red & 86.8 & 4.52 & 5.32 & 3.0 & 1.02 & 33.3 \\
\hline TH-1827 & Private & Round & Red & 78.4 & 4.40 & 5.18 & 3.2 & 0.56 & 64.9 \\
\hline No.108 & Private & Round & Red & 101.2 & 5.32 & 5.24 & 3.2 & 0.68 & 56.6 \\
\hline BSS-437 & Private & Pear Shaped & Red & 82.0 & 5.54 & 4.76 & 2.4 & 0.78 & 65.6 \\
\hline JKTH-2002 & Private & Pear Shaped & Red & 66.0 & 5.28 & 5.66 & 3.0 & 0.72 & 39.5 \\
\hline Roopsi & Private & Pear Shaped & $\begin{array}{l}\text { Light } \\
\text { Red }\end{array}$ & 58.0 & 5.12 & 4.18 & 2.2 & 0.70 & 42.0 \\
\hline BSS-423 & Private & Pear Shaped & Red & 83.0 & 5.46 & 4.93 & 2.3 & 0.78 & 62.1 \\
\hline Aruna & Private & $\begin{array}{l}\text { Flattish } \\
\text { Round }\end{array}$ & Red & 134.4 & 5.06 & 6.14 & 4.0 & 0.65 & 64.0 \\
\hline Kundal-90 & Private & Round & Red & 68.4 & 4.84 & 4.56 & 3.0 & 0.66 & 30.5 \\
\hline BCTH-4 & Public & Flattish Round & Red & 81.0 & 4.86 & 6.10 & 4.0 & 0.56 & 64.7 \\
\hline COTH-2 & Public & Round & Red & 105.0 & 4.88 & 5.58 & 4.0 & 0.58 & 45.9 \\
\hline VLTH-1 & Public & Round & Red & 95.0 & 4.85 & 5.52 & 4.3 & 0.52 & 56.9 \\
\hline TH-1359 & Private & Pear shaped & Red & 92.0 & 5.96 & 5.00 & 2.0 & 0.92 & 65.1 \\
\hline Vijay Lakshmi & Private & Flattish Round & Red & 84.0 & 4.14 & 5.72 & 3.1 & 0.54 & 60.4 \\
\hline Crystal-448 & Private & Pear shaped & $\begin{array}{l}\text { Light } \\
\text { Red }\end{array}$ & 115.0 & 6.48 & 5.96 & 3.0 & 0.68 & 47.7 \\
\hline \multicolumn{4}{|c|}{ Range } & $42.00-134.40$ & $3.18-6.48$ & $3.94-6.36$ & $2.0-4.4$ & $0.36-1.02$ & $30.50-79.00$ \\
\hline \multicolumn{4}{|c|}{ Mean } & 80.13 & 4.73 & 5.06 & 3.27 & 0.60 & 54.33 \\
\hline \multicolumn{4}{|c|}{ CD at $5 \%$} & 9.84 & 0.08 & 0.02 & 0.01 & 0.09 & 2.58 \\
\hline
\end{tabular}

Table 1: Physical characteristics of tomato hybrids.

\begin{tabular}{|c|c|c|}
\hline Character & $\begin{array}{l}\text { Pear shaped } \\
\text { red fruited hybrid }\end{array}$ & $\begin{array}{l}\text { Round shaped } \\
\text { red fruited hybrid }\end{array}$ \\
\hline Fruit weight $>80 \mathrm{~g}$ & $\begin{array}{l}\text { ARTH-1023; JKTH-2040, BSS-423, BSS-437, TH-1359, } \\
\text { Ajeet-11 }\end{array}$ & $\begin{array}{l}\text { Aruna, COTH-2, BCTH-62, No-108, BSS-571, BSS-575, VNR-6A, NTH-449, } \\
\text { VLTH-1, Vijay Lakshmi, BCTH-4 }\end{array}$ \\
\hline No. of locules (2-4) & $\begin{array}{l}\text { ARTH-1023; JKTH-2040, BSS-423, BSS-437, TH-1359, } \\
\text { ARTH-1001 }\end{array}$ & $\begin{array}{c}\text { Aruna, COTH-2, BCTH-62, No-108, BSS-571, BSS-575, VNR-6A, NTH-449, } \\
\text { VLTH-1, Vijay Lakshmi, BCTH-4 }\end{array}$ \\
\hline $\begin{array}{l}\text { Pericarp thickness > } \\
\quad 0.5 \mathrm{~cm}\end{array}$ & $\begin{array}{l}\text { JKTH-2040, ARTH-1023, BSS-437, ARTH-1001, Ajeet-11, } \\
\text { JKTH-2002, BSS-423, Roopsi, TH-1359 }\end{array}$ & $\begin{array}{l}\text { BCTH-62, BSS-571, BSS-575, HATH-5, NTH-449, TH-1827, No-108, Aruna, } \\
\text { Kundal-90, BCTH-4, COTH-2, VLTH-1, Vijay Lakshmi }\end{array}$ \\
\hline TSS $>4.5^{\circ}$ brix & BSS-423; TH-1359 & BCTH-62, HATH-9, No-108, Aruna, Kundal-90, COTH-2,BCTH-4, Vijay Lakshmi \\
\hline Acidity $>0.40 \%$ & ARTH-1001, BSS-423; TH-1359 & BCTH-4, Vijay Lakshmi, COTH-2, VLTH-1, SHTH-3, BSS-575, HATH-9, \\
\hline $\mathrm{pH}<4.5$ & BSS-423, ARTH-1023,TH-1359, Crystal-448 & $\begin{array}{c}\text { BCTH-62, Vijay Lakshmi,No-108, SHTH-3, SHTH-1, BSS-571, HTH-2-1, UKC-10, } \\
\text { HTH-2-2, HATH-5, JKTH-2002, BCTH-4, VLTH-1 }\end{array}$ \\
\hline $\begin{array}{l}\text { Vitamin } C>25 \\
\quad \mathrm{mg} / 100 \mathrm{~g}\end{array}$ & $\begin{array}{l}\text { ARTH-1001, BSS-437,Roopsi, TH-1359, Crystal-448, BSS- } \\
423\end{array}$ & VNR-6A, TH-1827, BCTH-4, COTH-2, VLTH-1, Vijay Lakshmi \\
\hline $\begin{array}{l}\text { Lycopene }>3.0 \\
\mathrm{mg} / 100 \mathrm{~g}\end{array}$ & BSS-423, ARTH-1001, ARTH-1023, TH-1359 & $\begin{array}{c}\text { BCTH-62, BCTH-4, NTH-449, HTH-2-2, VNR-6A, UKC-10, HTH-2-1, BSS-571, } \\
\text { SHTH-1, SHTH-3, Ajeet-11, Vijay Lakshmi }\end{array}$ \\
\hline
\end{tabular}

Table 2: Selection of promising hybrids for processing purpose.

shaped and seven round shaped red coloured hybrids possessed acidity of more than $0.40 \%$ (Table 2). Tomatoes are not a low-acid food and thus require less drastic thermal treatments than foods classified as low acid $(\mathrm{pH}>4.6)$ for the destruction of spoilage microorganisms to ensure food safety. It has been suggested that $\mathrm{pH} 4.4$ is the maximum desirable for safety and the optimum target $\mathrm{pH}$ should be 4.25 [26]. Industrial processors of tomatoes in California typically specify a $\mathrm{pH}$ of 4.2 or 4.3 in their processed products. The $\mathrm{pH}$ of tomatoes is determined 
Citation: Chattopadhyay A, Chakraborty IVI, Siddique W (2013) Characterization of Determinate Tomato Hybrids: Search for Better Processing Qualities. J Food Process Technol 4: 222. doi:10.4172/2157-7110.1000222

Page 4 of 6

primarily by the acid content of the fruit. The minimum $\mathrm{pH}(3.70)$ of the fruit was recorded in HATH-5 and the maximum (5.40) was shown by ARTH-1001 (Table 3). Four pear shaped and thirteen round shaped red coloured hybrids showed a $\mathrm{pH}$ value of less than 4.5 (Table 2).

High ascorbic acid in tomato not only improves the nutrition, it also aids in better retention of natural colour and flavour of the products [16]. In the present study, a significant variation was recorded for ascorbic acid content, maximum being in BCTH-4 $(40.50 \mathrm{mg} / 100 \mathrm{~g})$ and minimum in No-108 (14.63 mg/100 g). A wide range of genotypic variation in the ascorbic acid content was recorded by various workers [25,27-28]. Six each of pear and round fruited red coloured hybrids exhibited ascorbic acid content of more than $25 \mathrm{mg} / 100 \mathrm{~g}$ (Table 2).

Colour of fruit is an important quality parameter both for table purpose and processing varieties. Potaczek and Michalik [29] have observed that environmental factors especially temperature and light intensity exerted a great influence on lycopene level than on carotene

\begin{tabular}{|c|c|c|c|c|c|c|}
\hline Entries & $\begin{array}{c}\text { TSS } \\
\left({ }^{\circ} \text { Brix }\right)\end{array}$ & $\begin{array}{c}\text { Acidity } \\
(\%)\end{array}$ & $\mathrm{pH}$ & Vitamin C (mg/100g) & $\begin{array}{l}\text { Lycopene } \\
\text { (mg/100g) }\end{array}$ & $\begin{array}{l}\text { Total carotenoids } \\
(\mathbf{m g} / \mathbf{1 0 0 g})\end{array}$ \\
\hline ВСТH-62 & 4.52 & 0.35 & 3.9 & 21.14 & 4.91 & 7.26 \\
\hline Ajeet-11 & 4.36 & 0.38 & 5.2 & 21.83 & 3.28 & 4.39 \\
\hline ARTH-1023 & 4.26 & 0.28 & 4.0 & 22.00 & 3.90 & 4.67 \\
\hline SHTH-3 & 4.08 & 0.44 & 3.6 & 21.00 & 3.72 & 4.49 \\
\hline SHTH-1 & 4.00 & 0.27 & 4.3 & 24.00 & 3.70 & 4.28 \\
\hline BSS-571 & 4.48 & 0.32 & 4.2 & 18.94 & 4.00 & 5.07 \\
\hline BSS-575 & 4.04 & 0.41 & 4.6 & 21.00 & 2.95 & 3.27 \\
\hline HTH-2-1 & 4.28 & 0.39 & 4.0 & 24.98 & 3.28 & 4.27 \\
\hline UKC-10 & 4.14 & 0.33 & 4.0 & 23.00 & 3.68 & 4.20 \\
\hline VNR-6A & 4.20 & 0.38 & 5.1 & 26.00 & 3.42 & 4.10 \\
\hline HTH-2-2 & 4.10 & 0.38 & 4.2 & 21.96 & 4.70 & 6.98 \\
\hline ARTH-3 & 4.12 & 0.40 & 4.8 & 18.00 & 1.30 & 2.76 \\
\hline ARTH-1001 & 4.14 & 0.50 & 5.4 & 28.90 & 3.60 & 4.17 \\
\hline HATH-5 & 4.28 & 0.32 & 3.7 & 24.30 & 2.28 & 3.60 \\
\hline HATH-9 & 4.80 & 0.44 & 5.2 & 17.12 & 2.26 & 3.52 \\
\hline NTH-449 & 3.84 & 0.42 & 4.7 & 19.00 & 4.62 & 6.25 \\
\hline JKTH-2040 & 3.92 & 0.39 & 4.6 & 21.04 & 2.21 & 3.48 \\
\hline TH-1827 & 4.00 & 0.42 & 4.6 & 27.52 & 1.64 & 3.04 \\
\hline No-108 & 4.86 & 0.30 & 4.2 & 14.63 & 1.92 & 3.40 \\
\hline BSS-437 & 4.04 & 0.38 & 5.0 & 27.62 & 2.25 & 3.58 \\
\hline JKTH-2002 & 4.00 & 0.40 & 4.2 & 19.00 & 1.90 & 3.24 \\
\hline Roopsi & 3.82 & 0.37 & 5.0 & 25.10 & 1.98 & 3.51 \\
\hline BSS-423 & 4.90 & 0.35 & 4.1 & 25.93 & 3.37 & 4.02 \\
\hline Aruna & 4.80 & 0.29 & 5.3 & 16.00 & 1.94 & 3.29 \\
\hline Kundal-90 & 5.00 & 0.38 & 5.2 & 21.00 & 2.72 & 3.70 \\
\hline BCTH-4 & 4.74 & 0.51 & 4.2 & 40.50 & 3.13 & 4.07 \\
\hline COTH-2 & 4.48 & 0.42 & 4.9 & 26.50 & 1.45 & 2.60 \\
\hline VLTH-1 & 4.36 & 0.43 & 4.2 & 33.50 & 1.43 & 2.53 \\
\hline TH-1359 & 4.52 & 0.41 & 4.3 & 35.30 & 3.10 & 3.90 \\
\hline Vijay Lakshmi & 5.10 & 0.52 & 4.3 & 31.00 & 3.15 & 4.12 \\
\hline Crystal-448 & 4.20 & 0.27 & 4.2 & 34.25 & 1.25 & 2.42 \\
\hline Range & $3.82-5.10$ & $0.27-0-52$ & $3.70-5-40$ & $14.63-40.50$ & $1.25-4.91$ & $2.42-7.26$ \\
\hline Mean & 4.33 & 0.38 & 4.49 & 24.26 & 2.87 & 4.00 \\
\hline CD at $5 \%$ & 0.05 & 0.03 & 0.07 & 2.30 & 0.15 & 0.17 \\
\hline
\end{tabular}

Table 3: Biochemical composition of tomato hybrids.

\begin{tabular}{|c|c|c|c|c|c|c|c|c|c|}
\hline Characters & ED & LN & PT & TSS & TAC & PH & VITC & LYCO & TCAR \\
\hline$P D^{a}$ & 0.270 & -0.280 & $0.606^{* *}$ & 0.134 & -0.243 & 0.074 & 0.171 & -0.263 & 0.185 \\
\hline ED & & $0.456^{* *}$ & 0.181 & 0.183 & 0.072 & -0.061 & 0.143 & -0.116 & -0.139 \\
\hline LN & & & $-0.405^{*}$ & 0.163 & 0.152 & -0.132 & -0.076 & -0.105 & $-0.385^{*}$ \\
\hline PT & & & & -0.025 & -0.076 & 0.097 & 0.060 & -0.263 & 0.141 \\
\hline TSS & & & & & 0.085 & 0.231 & 0.010 & -0.090 & -0.127 \\
\hline TAC & & & & & & 0.343 & $0.373^{*}$ & -0.014 & 0.193 \\
\hline $\mathrm{PH}$ & & & & & & & -0.026 & -0.249 & 0.050 \\
\hline VITC & & & & & & & & -0.134 & -0.105 \\
\hline LYCO & & & & & & & & & $0.434^{*}$ \\
\hline
\end{tabular}

a PD: Polar diameter; ED: Equatorial diameter; LN: Locule number; PT: Pericarp thickness; TSS: Total soluble solids; TAC: Titratable acidity; PH: pH of the fruit; VITC: Vitamin C; LYCO: Lycopene; TCAR: Total carotenoids

${ }^{*}$ and ${ }^{* *}$ significant at $5 \%$ and $1 \%$ level of significance, respectively

Table 4: Pearson's correlation matrix of all variables. 
contents in tomato fruits. Red-fruiting cultivars also have higher lycopene content than yellow, orange and black- fruiting cultivars [30]. Lycopene synthesis during growth is inhibited at temperatures below $12^{\circ} \mathrm{C}$ and prohibited at $>32^{\circ} \mathrm{C}$. Hybrids rich in lycopene generally produced bright red or deep red hues whereas hybrids with least amount of lycopene content were orange red or light red in colour. Such wide range (1.25-4.91 $\mathrm{mg} / 100 \mathrm{~g})$ was observed among the hybrids studied with maximum $4.91 \mathrm{mg} / 100 \mathrm{~g}$ in BCTH-62, followed by 4.70 $\mathrm{mg} / 100 \mathrm{~g}$ in HTH-2-2 and $4.62 \mathrm{mg} / 100 \mathrm{~g}$ in NTH-449 while minimum of $1.25 \mathrm{mg} / 100 \mathrm{~g}$ in Crystal-448. There was a wide genotypic range of lycopene was observed by Mangels et al. [31]. Four pear shaped and twelve round shaped red coloured hybrids possessed lycopene of more than $3.0 \mathrm{mg} / 100 \mathrm{~g}$ (Table 2). Likewise, total carotenoids content ranged from $2.42 \mathrm{mg} / 100 \mathrm{~g}$ to $7.26 \mathrm{mg} / 100 \mathrm{~g}$ among the hybrids. The maximum content was found in BCTH-4 with $7.26 \mathrm{mg} / 100 \mathrm{~g}$ and the minimum $2.42 \mathrm{mg} / 100 \mathrm{~g}$ in Crystal-448 (Table 3).

The correlation study (Table 4) among different physico-chemical parameters indicated some significant positive relationship between polar diameter and pericarp thickness, equatorial diameter and locule number, titratable acidity and ascorbic acid content, and lycopene and total carotenoids content of the fruit. Similarly, some significant negative associationship between locule number and pericarp thickness, and locule number and total carotenoids content of fruit has been observed.

From the combined study of different physico-chemical parameters of the hybrids, two pear shaped private bred hybrids (BSS-423; TH1359) and three round shaped public (BCTH-62 and BCTH-4) and private (Vijay Lakshmi) bred hybrids have been identified as most suitable for processing purpose (Table 5). The yield potentialities of these hybrids were recorded to be more than $60.0 \mathrm{t} /$ ha (Figure 1).

\begin{tabular}{|c|c|c|}
\hline Combined characters & $\begin{array}{l}\text { Pear shaped } \\
\text { hybrid }\end{array}$ & $\begin{array}{l}\text { Round shaped } \\
\text { hybrid }\end{array}$ \\
\hline $\begin{array}{l}\text { Fruit weight > } 80 \mathrm{~g} \text {; No. of locules }(2-4) \text {; } \\
\text { Pericarp thickness > } 0.5 \mathrm{~cm} \text {; TSS }>4.5^{0} \\
\text { brix; Acidity > } 0.40 \% \text {; } \\
\text { pH < 4.5; Vitamin C > } 25 \mathrm{mg} / 100 \mathrm{~g} ; \\
\text { Lycopene }>3.0 \mathrm{mg} / 100 \mathrm{~g}\end{array}$ & BSS-423; TH-1359 & $\begin{array}{l}\text { BCTH-62, Vijay } \\
\text { Lakshmi, BCTH-4 }\end{array}$ \\
\hline
\end{tabular}

Table 5: Identification of most promising hybrids for processing.

Yield (t/ha) potentialities of promising processing hybrids

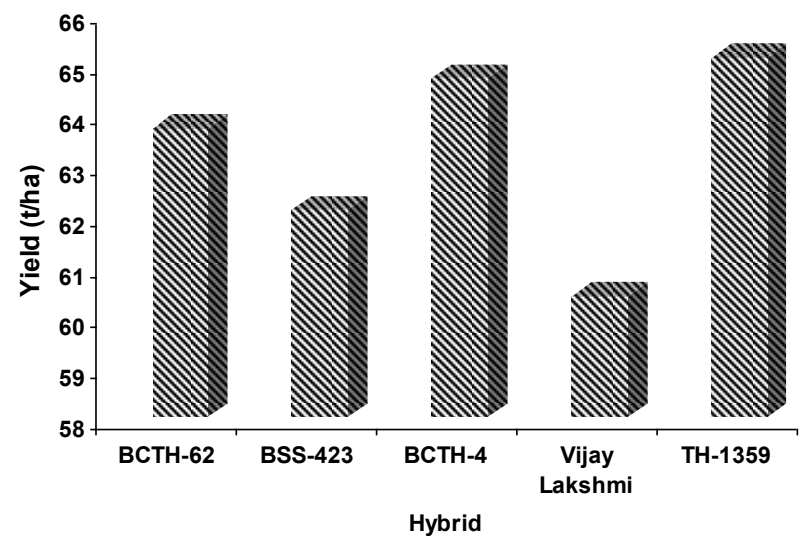

Figure 1: Yield performance of five promising processing hybrids

\section{Conclusions}

Normally pear/oblong shaped variety/hybrid with lower locule number is generally preferred for processing. In the present study, two pear shaped (BSS-423; TH-1359) and three round shaped (BCTH62, BCTH-4, and Vijay Lakshmi) hybrids were adjudged as most promising for processing purpose. These hybrids could also be grown by the farmers as table purpose during autumn-winter season of the Gangetic plains of eastern India owing to their high yield potentialities and other desirable characteristics.

\section{References}

1. Ranieri A, Giuntini D, Lercari B, Soldatini GF (2004) Light influence on antioxidant properties of tomato fruits. Progress in Nutrition 6: 44-49.

2. Kaur C, George B, Deepa N, Singh B, Kapoor HC (2004) Antioxidant status of fresh and processed tomato-A review. J Food Sci Technol 41: 479-486.

3. Madhavi DL, Salunkhe DK (1998) Handbook of Vegetable Science and Technology: Production, Composition, Storage and Processing ed by Sakunkhe, D.K., Kadam, S,S. Marcel Dekker Inc, New York, USA.

4. Gopalan C, Rama Shastri BV, Balasubramanian SC (1989) Nutritive Value of Indian Foods. National Institute of Nutrition, ICMR, Hyderabad, India.

5. Trout DL (1991) Vitamin C and cardiovascular risk factors. Am J Clin Nutr 53 322S-325S.

6. Raffo A, Leonardi C, Fogliano V, Ambrosino P, Salucci M, et al. (2002) Nutritional value of cherry tomatoes (Lycopersicon esculentum Cv. Naomi F1) harvested at different ripening stages. J Agric Food Chem 50: 6550-6556.

7. Balasubramanian $T(1984)$ Studies on quality and nutritional aspects of tomato J Food Sci Technol 21:419-421.

8. Adsule PG, Dan A, Tikko SK (1980) Studies on the evaluation of tomato cultivars for making juice. Indian Food Packer 34: 18-20.

9. Anonymous (2009) Report of National Horticulture Board, Indian Horticulture Database, Ministry of Agriculture, Government of India, New Delhi, India.

10. Chattopadhyay A, Dutta S, Bhattacharya I, Karmakar K, Hazra P (2007) Technology for Vegetable Crop Production. Published by All India Coordinated Research Project on Vegetable Crops, Directorate of Research, Bidhan Chandra Krishi Viswavidyalaya, Kalyani-741235, Nadia, West Bengal, India.

11. Renquist AR, Reid JB (2008) Quality of processing tomato (Lycoperscion esculentum) fruit from four bloom dates in relation to optimal harvest timing New Zeal J Crop Hort 26: 161-168.

12. AOAC (1984) Official Methods of Analysis. (14th ed), Washinton DC, USA

13. Ranganna S (1976) Manual of Analysis of Fruit and Vegetable Products. Tata McGraw-Hill Publishing Company Ltd, India.

14. Gomez KA, Gomez AA (1984) Statistical Procedures for Agricultural Research John Willey and Sons, New York, USA.

15. Tiwari RN (1996) Scope for better processing and export in tomato using F1 hybrids, in Training Manual on vegetable hybrids and their seed production published by IARI, New Delhi, India.

16. Thamburaj S (1998) Breeding for high quality vegetable, in Souvenir of Nationa Symposium on Emerging Scenario in Vegetable Research and Development published by IIVR, Varanasi, India.

17. Thakur NS, Kaushal LBB (1995) Study of quality characteristics of some commercial varieties and F1 hybrids of tomato grown in Himachal Pradesh in relation to processing, Indian Food Packer.

18. Chakraborty IVI, Vanlalliani, Chattopadhyay A, Pranab H (2007) Studies on Processing and Nutritional Qualities of Tomato as Influenced by Genotypes and Environment. Vegetable Science 34: 26-31.

19. Raina BR, Karla CL, Teotia MS, Rodriques R, Nandpuri KS, et al. (1980) Studies on suitability of some tomato lines and varieties for processing. Vegetable Science 7: 60-66.

20. Kumari A, Grewal BB, Banerjee MK, Kumari A (1998) Assessment of physicochemical characteristics of different tomato (Lycopersicon esculentum Mill.) genotypes. Vegetable Science 25:127-130.

21. Bhutani RD, Kalloo G (1991) Inheritance studies of locule number in tomato Haryana J Hort Sci 20: 119-124. 
Citation: Chattopadhyay A, Chakraborty IVI, Siddique W (2013) Characterization of Determinate Tomato Hybrids: Search for Better Processing Qualities. J Food Process Technol 4: 222. doi:10.4172/2157-7110.1000222

22. Anthon GE, LeStrange $\mathrm{M}$, Barrett DM (2011) Changes in $\mathrm{pH}$, acids, sugars and other quality parameters during extended vine holding of ripe processing tomatoes. J Sci Food Agric 91: 1175-1181.

23. Paulson KN, Stevens MA (1974) Relationships Among Titratable Acidity, pH and Buffer Composition of Tomato Fruit. J Food Sci 39: 354-357.

24. Davies JN, Hobson GE (1981) The constituents of tomato fruit--the influence of environment, nutrition, and genotype. Crit Rev Food Sci Nutr 15: 205-280.

25. Ereifej KI, Shibli RA, Ajlouni MM, Hussain A (1997) Physico-chemical characteristics and processing quality of newly introduced seven tomato cultivars into Jordan in comparison with local variety. J Food Sci Technol 34: 171-174.

26. Monti LM (1980) The breeding of tomatoes for peeling. Acta Horticulturae 100 341-353
27. Kalloo G, Bhutani RD (1993) Advances in Horticulture, in Vegetable Crops.

28. Adubofuor J, Amankwah EA, Arthur BS, Appiah F (2010) Comparative study related to physico-chemical properties and sensory qualities of tomato juice and cocktail juice produced from oranges, tomatoes and carrots. African Journal of Food Science 4: 427- 433.

29. Potaczek H, Michalik H (1988) Improvement of the nutritional value of tomato (Lycopersicon esculentum Mill.) by means of breeding for quality. Vegetable Crops Research Bulletin 49: 13-20.

30. Cox SE, Stushnoff C, Sampson DA (2003) Relationship of fruit color and light exposure to lycopene content and antioxidant properties of tomato. Can J Plan Sci 83: 913-919.

31. Mangels AR, Holden JM, Beecher GR, Forman MR, Lanza E (1993) Carotenoid content of fruits and vegetables: an evaluation of analytic data. J Am Diet Assoc 93: 284-296. 